The Auk 122(4):1130-1148, 2005

(C) The American Ornithologists' Union, 2005.

Printed in USA.

\title{
LONG-TERM TRENDS IN SPRING ARRIVAL DATES OF MIGRANT BIRDS AT DELTA MARSH, MANITOBA, IN RELATION TO CLIMATE CHANGE
}

\author{
Heather M. Murphy-Klassen, Todd J. Underwood, ${ }^{1}$ Spencer G. Sealy, \\ and Ashleigh A. CZyrnyj \\ Department of Zoology, University of Manitoba, Winnipeg, Manitoba R3T 2N2, Canada
}

\begin{abstract}
Aвstract. - We examined a 63-year data set of dates of first spring sightings for 96 species of migrant birds at Delta Marsh, Manitoba, and considered the influence of local climate change on those arrival dates. Mean monthly spring temperatures increased $\left(0.6-3.8^{\circ} \mathrm{C}\right)$ for all four months considered; however, trends for February and March were stronger than those for April and May. Over the 63-year period, 27 species significantly altered their arrival dates. Most of those species arrived significantly earlier; whereas only two species, Greater Yellowlegs (Tringa melanoleuca) and Lesser Yellowlegs (T. flavipes), arrived significantly later over time. About half of the migrants showed significant relationships between arrival dates and mean temperature for their month of arrival. Fifteen species showed significantly earlier arrivals over time and a significant relationship between arrival date and temperature. We also characterized migrants by taxon, breeding status, and wintering location to determine whether there were any trends for altered arrivals within certain groups. Waterfowl, species that breed at Delta Marsh, and short-distance migrants showed slightly higher incidences of advancing arrival dates compared with other groups. Our results provide evidence that climate warming has influenced spring migration arrival dates of several species in Manitoba. Received 7 December 2003, accepted 1 March 2005.
\end{abstract}

Key words: climate change, long-distance migrants, long-term study, Manitoba, migration, short-distance migrants, spring arrivals.

Tendances à Long-terme des Dates d'Arrivée Printanières des Oiseaux Migrateurs dans le Delta Marsh, Manitoba, en Relation avec les Changements Climatiques

RÉsumé.-Nous avons examiné un ensemble de données de 63 ans contenant les dates des premières observations printanières de 96 espèces d'oiseaux migrateurs dans le Delta Marsh, Manitoba. Nous avons considéré l'influence des changements climatiques locaux sur ces dates d'arrivée. Les températures printanières mensuelles ont augmenté $\left(0,6-3,8^{\circ} \mathrm{C}\right)$ pour toutes les périodes de quatre mois considérées. Néanmoins, les tendances pour février et mars étaient plus fortes que celles pour avril et mai. Au cours des 63 années analysées, 27 espèces ont significativement modifié leur date d'arrivée. La plupart de ces espèces arrivaient significativement plus tôt et seules deux espèces, Tringa melanoleuca et T. flavipes, sont arrivées significativement plus tard au cours du temps. Environ la moitié des oiseaux montrait des relations significatives entre les dates d'arrivée et la température moyenne de leur mois d’arrivée. Quinze espèces sont arrivées significativement

\footnotetext{
${ }^{1}$ Address correspondence to this author. Present address: Department of Biology, Kutztown University, Kutztown, Pennsylvania 19530, USA. E-mail: underwoo@kutztown.edu
} 
plus tôt au cours du temps et ont montré une relation significative entre la date d'arrivée et la température. Nous avons également caractérisé, par taxon, les statuts reproducteurs et les sites d'hivernage pour déterminer s'il existait des tendances dans les modifications de la date d'arrivée au sein des groupes. Les espèces de sauvagine qui nichent à Delta Marsh et celles qui migrent sur de courtes distances présentaient dates d'arrivée avancées dans une proportion légèrement plus élevée que d'autres groupes. Nos résultats fournissent des preuves que le réchauffement climatique a influencé les dates d'arrivée de plusieurs espèces au Manitoba lors de la migration printanière.

Global temperatures have risen $0.3-0.6^{\circ} \mathrm{C}$ since the late 19th century (Houghton et al. 1996). During the 20th century, annual mean temperature in southern Canada has risen $0.5-1.5^{\circ} \mathrm{C}$ (Zhang et al. 2000). This trend in climate warming has the potential to affect lifehistory patterns in many groups of organisms, including birds (Parmesan and Yohe 2003). The predicted effects of climate warming on avian populations worldwide include earlier breeding, larger clutch sizes, increased survivorship of high-latitude residents, and changes in diet attributable to altered phenology of food resources (Moss 1998), as well as expansion of certain breeding ranges and earlier arrival dates of migrant species (Žalakevičius 1999). Recently, researchers have begun to address changes over time in many aspects of avian life histories.

Most studies of birds in relation to climate change have focused on trends in clutch initiation dates, especially in European species. Earlier clutch initiation dates have been linked in several species with increasing spring temperatures or warmer winters (Forchhammer et al. 1998, Przybylo et al. 2000, Koike and Higuchi 2002). For example, Crick et al. (1997) revealed significantly earlier clutch initiation in 20 of 65 species in Britain and, on average, laying dates advanced 9 days over the 25-year study. However, earlier trends have not been recorded in all localities. Since 1970, Great Tits (Parus major) initiated their clutches earlier in Britain (McCleery and Perrins 1998); but in the Netherlands, Great Tits did not advance their laying dates, despite warmer spring temperatures (Visser et al. 1998).

Studies of clutch initiation dates in relation to climate warming are less common in North America. Tree Swallows (Tachycineta bicolor) initiated clutches earlier across North America in conjunction with increasing temperatures (Dunn and Winkler 1999), but clutch size was not affected by the timing of breeding (Winkler et al. 2002). Similarly, Mexican Jays (Aphelocoma ultramarina) showed a trend toward earlier clutch initiation, and that was related to increasing minimum monthly temperatures (Brown et al. 1999). By contrast, Hussell (2003) found no significant changes in spring temperature and, concurrently, discovered no evidence of altered clutch initiation dates for Tree Swallows in southern Ontario. However, he did observe a correlation between spring temperatures and clutch initiation dates. The evidence for advanced breeding phenologies in some European and North American birds suggests that migration also may be influenced by climate warming.

Fewer studies have assessed the trends in first arrival dates of migrants, and most have focused on European birds. In Poland, Tryjanowski et al. (2002) revealed trends toward earlier spring arrival dates in 14 of 16 species over a 26-year period. However, two studies in Britain found that about half of the spring migrants examined arrived earlier over time, whereas the other half arrived later (Sparks 1999, Jenkins and Watson 2000). By contrast, arrival dates of migrants in Norway have not advanced; however, there was also no evidence of climate warming in this country (Barrett 2002). Similarly, Pied Flycatchers (Ficedula hypoleuca) did not arrive earlier in spring, despite advanced plant phenology on their breeding grounds (Both and Visser 2001). In general, trends appear to vary within a given area and between regions.

Recently, trends in spring arrival dates of North American birds in relation to climate warming have begun to be addressed. Inouye 
et al. (2000) found that American Robins (Turdus migratorius) arrived earlier at higheraltitude breeding areas when phenology of vegetation advanced on the wintering grounds at lower elevations, but this earlier arrival was not statistically significant. In Alberta, Lane and Pearman (2003) observed a significant relationship between increasing March temperatures and earlier spring arrival for Mountain Bluebirds (Sialia currucoides), but not for Tree Swallows in the same area. In Wisconsin, Bradley et al. (1999) found that $35 \%$ of 17 spring migrants arrived significantly earlier over a 61-year period. In a similar but larger study, Butler (2003) revealed that $27 \%$ of 103 species showed significant trends toward earlier spring arrival between 1903 and 1993 in New York and Massachusetts and that shortdistance migrants arrived considerably earlier than long-distance migrants. However, trends toward earlier arrivals have not been found in all studies. In Maine, Wilson et al. (2000) compared the spring arrival dates for 80 species of migratory birds between 1899 and 1911 with those in 1994 through 1997. Surprisingly, of the 29 species with significant trends over time, $69 \%$ showed significantly later trends in arrival date. Thus, these conflicting trends in spring arrival dates of migratory birds in North America warrant further study, especially in other regions.

Here, we examined trends in the spring arrival dates of 96 species of migrants over the past six decades at Delta Marsh, Manitoba. We determined whether the observed trends in arrival dates were linked to local climate change and annual variability in spring temperatures and whether patterns existed for certain groups based on taxonomy, migratory distance, and breeding location. Climatic models have predicted a temperature increase in Manitoba of $4-6^{\circ} \mathrm{C}$ between 1990 and 2100 because of the higher latitude of this province and its central location in North America, compared with a global increase of $1.4-5.8^{\circ} \mathrm{C}$ (International Institute for Sustainable Development and Manitoba Clean Environment Commission 2001). Additionally, Manitoba is predicted to experience warmer, wetter springs and a longer growing season. Therefore, Delta Marsh is an ideal site to examine the potential influence of climate change on spring arrival dates of migrant birds in North America.
Methods

Study Site

Located in south-central Manitoba, Delta Marsh $\left(50^{\circ} 11^{\prime} \mathrm{N}, 98^{\circ} 24^{\prime} \mathrm{W}\right.$, elevation $\left.248 \mathrm{~m}\right)$ is one of the largest marshes on the Canadian prairies and is separated from a large freshwater lake, Lake Manitoba, by a narrow dune-ridge forest. Other habitats in the area include large bays, wet meadows, aspen parkland, and oak woods (for detailed descriptions of the area, see MacKenzie 1982, MacKenzie et al. 1982, Shay 1999). Delta Marsh is an important stopover site for many migratory bird species and supports high breeding densities of some songbirds (MacKenzie et al. 1982, Hobson et al. 1993, den Haan 1997, Underwood and den Haan 2000).

\section{Data Collection}

The first spring sightings of migratory birds were recorded annually at the Delta Waterfowl and Wetlands Research Station from 1939 to 2001, excluding three years during which data were not collected (1993, 1995, and 1996). Dates of first spring sightings for 231 species were recorded. Many of those species were rare or uncommon at the site, and a few have colonized the area only in the past 25 years (e.g. Sealy 1980). Therefore, some of those species were not present in all years or were present in low numbers, and their arrival dates were not recorded every year. For that reason, we analyzed trends for species that were observed in $\geq 40$ years over the 63-year period (i.e. recorded in $\geq 64 \%$ of total years). Additionally, we ensured that for each species there was a minimum of two records during both the first and last 10 years of the study and that at least one record was from each of the first and last five years. Of the 231 species for which records of first spring arrival dates exist, 96 species from 14 orders were represented in our data set. In a few cases, arrival dates appeared to be recorded erroneously, such as a Yellow-bellied Sapsucker (see Appendix for scientific names of birds) arriving on 15 September 1999. We removed this and a few other similar dates from the data set. Because the vernal equinox is becoming progressively earlier, there is a possibility for spring phenomena to appear earlier as well (Sagarin 2001). To correct for this, we adjusted 
our data for temperature and arrival dates following Hussell (2003).

The potential biases of volunteer-based studies with many observers are well known, such as observation effort measured by the number of observers or their ability to identify birds (Robbins et al. 1986). However, Mason (1995) pointed out that migration analyses like ours are based on long-term trends; hence, problems of variation around data points are likely to be minimal. We are confident that the level of skill of the observers involved and the temporal extent of these data reduce any potential biases present. In addition, we recognize that first sightings in spring do not necessarily imply the presence of most of the population for a given species. Sparks (1999) also cautioned that first observations may be related to the size of a species' population, but the extent of that influence is unknown. We believe that first sightings consistently recorded at Delta Marsh are adequate for assessing longterm trends in spring migration.

For analyses related to climate change, we used weather data from Winnipeg, Manitoba, which is $\sim 90 \mathrm{~km}$ southeast of Delta. This was the location nearest the study area where temperature data have been recorded over the entire 63year study period. Mean monthly temperatures for February through May were obtained for the Winnipeg International Airport $\left(49^{\circ} 55^{\prime} \mathrm{N}\right.$, $97^{\circ} 14^{\prime} \mathrm{W}$; elevation $239 \mathrm{~m}$ ) from 1939 to 2001 . To justify the use of these data, we compared temperatures recorded at Winnipeg with those at Delta Marsh for 1968-2000 when temperatures from both sites were available. Mean monthly temperatures for Winnipeg were significantly related to those at Delta Marsh for February $\left(r^{2}=0.932, P<0.001\right)$, March $\left(r^{2}=0.954, P<\right.$ 0.001), April $\left(r^{2}=0.925, P<0.001\right)$, and May $\left(r^{2}=0.896, P<0.001\right)$.

Treatment of Data and Statistical Analysis

Birds were categorized to order following the American Ornithologists' Union Check-list of North American Birds (1998) and classified into groups of migrants based on their overwintering areas using Hagan et al.'s (1991) approach. We used the Birds of North America species accounts (Poole and Gill 1992-2002) to identify ranges of species that wintered predominantly in North America, Central America (including Mexico), South America, or a combination thereof. We considered species that wintered predominantly in North America to be short-distance migrants and those that wintered in Central America or South America to be long-distance migrants. Species were also identified as breeders or nonbreeders at Delta Marsh on the basis of a checklist of birds for the area (Underwood and den Haan 2000). While examining trends based on species groups, we focused on the three orders that were represented by more than six species each: Anseriformes, Charadriiformes, and Passeriformes.

To analyze long-term trends in arrival dates, we converted conventional dates into Julian dates. In some cases, we converted Julian dates back to a conventional format when reporting results. To examine the variability in mean arrival date over the spring season, we documented the relationship between mean arrival dates for all 96 species and their standard deviations using linear regression. We used standard deviation instead of the coefficient of variation (e.g. Mason 1995) because the coefficient of variation can only be used with ratio-scale data (Zar 1999). We also regressed arrival dates of each species with year as the independent variable to determine whether there were significant trends in migration dates over time.

We examined whether arrival dates were related to temperature for all 96 species by using linear regression to compare spring arrival dates and average monthly temperatures. We selected the temperatures from one month based on the mean date of arrival for each species (see Appendix). For example, if the mean date of arrival of a species was 15 April, we used mean monthly temperatures for April. Statistical analyses were performed using SPSS 11.0, and we used a significance level of $P=0.05$.

\section{Results}

\section{General Observations}

The Horned Lark had the earliest mean arrival date, 24 February, whereas the Common Nighthawk arrived last, 19 May (Appendix). Most mean arrival dates occurred in April, with 57 of the 96 species arriving during this month. Species that arrived earlier in the season showed significantly more variability in arrival date than those that returned later $\left(r^{2}=0.194\right.$, $P<0.001$; Fig. 1). Arrival dates of the Horned 


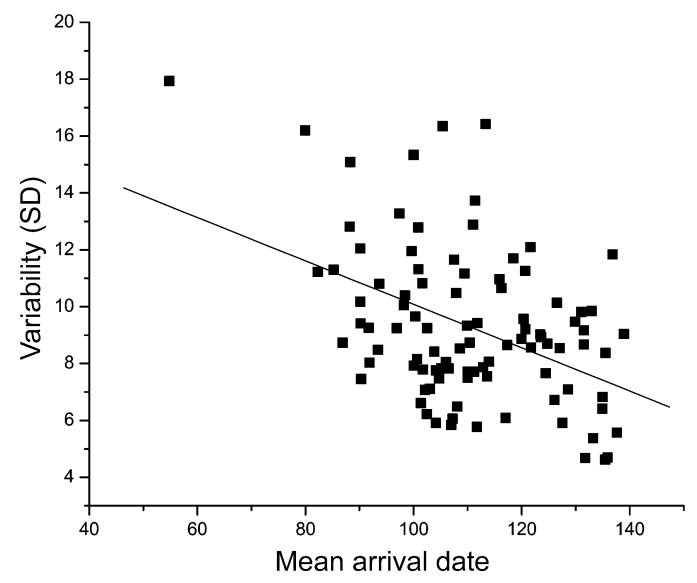

FIG. 1. Variability (SD) in arrival dates in relation to mean arrival dates (Julian) of 96 species of migrants (1939-2001) at Delta Marsh, Manitoba. Arrival dates are as follows: January (1-31), February (32-59), March (60-90), April (91-120), and May (121-151).
Lark were the most variable of all species, whereas arrival dates of the Yellow Warbler showed the lowest standard deviation (Appendix).

\section{Analysis of Weather Trends}

Mean monthly temperatures from the Winnipeg International Airport (1939-2001) consistently increased over time for each month during February through May. However, the trends for February and March were stronger than those for April and May (February: $r^{2}=$ 0.092, $P=0.016$; March: $r^{2}=0.067, P=0.040$; April: $r^{2}=0.005, P=0.569$; May: $r^{2}=0.034$, $P=0.147$; Fig. 2). From the regression equations (February: $y=0.062 x-135.52$; March: $y=$ $0.050 x-105.42$; April: $y=0.010 x-16.39$; May: $y=0.022 x-32.35)$, the changes in temperature by month were $3.8^{\circ} \mathrm{C}$ in February, $3.1^{\circ} \mathrm{C}$ in March, $0.6^{\circ} \mathrm{C}$ in April, and $1.4^{\circ} \mathrm{C}$ in May.
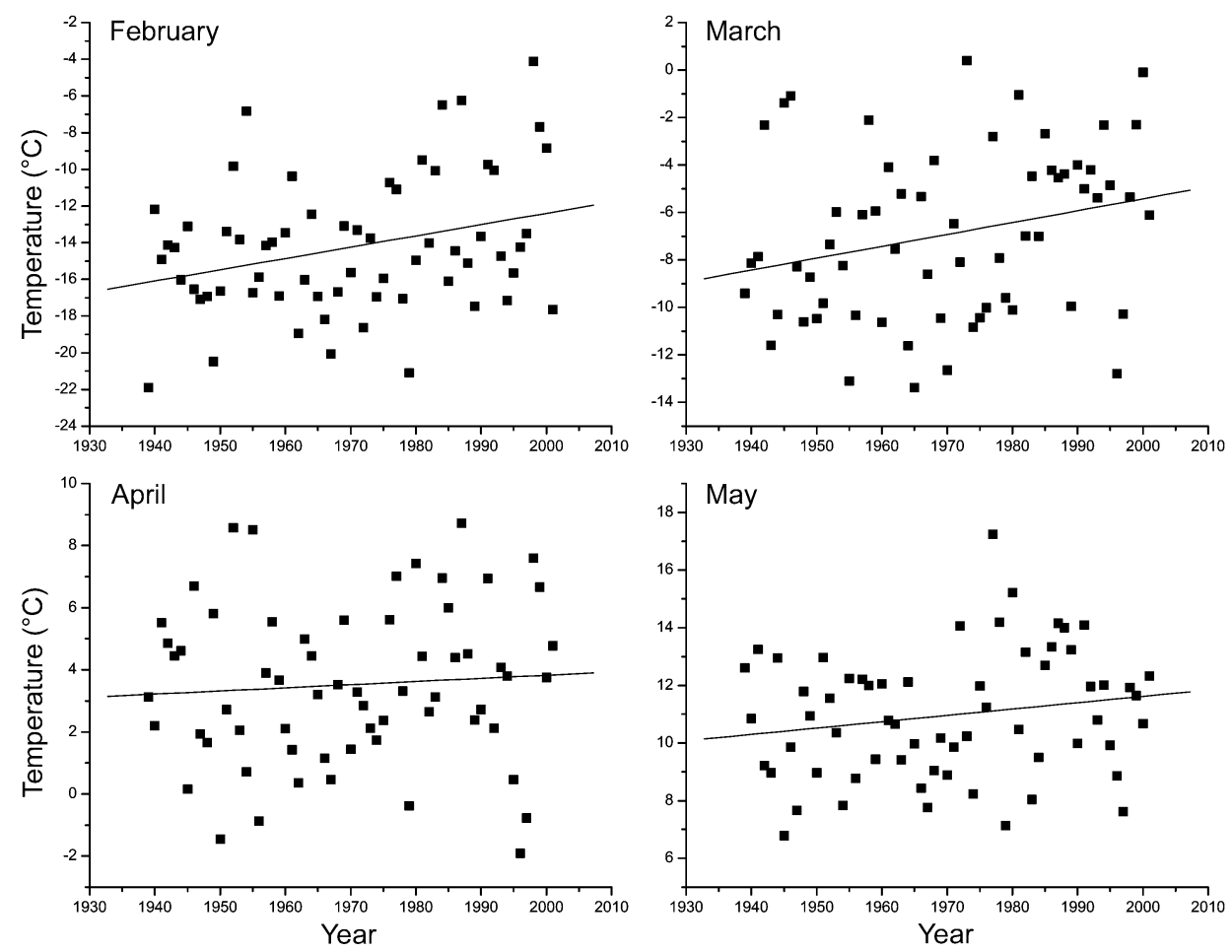

FIG. 2. Trends in mean monthly temperatures over time (1939-2001) at the Winnipeg International Airport, February through May. 


\section{Trends OVer Time}

Of the 96 species of migrants examined, the trends for 27 were significant over time (Fig. 3; Appendix). Greater and Lesser yellowlegs arrived significantly later as the years progressed, whereas the other 25 species arrived significantly earlier. Of the remaining 69 species with nonsignificant trends, 19 showed positive trends in arrival date over time; whereas 50 showed negative trends, indicating earlier arrival. Of the orders that contained more than six species, $100 \%(n=21)$ of the Anseriformes, $38 \%(n=13)$ of the Charadriiformes, and $79 \%$ $(n=39)$ of the Passeriformes showed trends toward earlier arrival, whether significant or not (Appendix).

Several species advanced their arrival dates substantially over the 63-year period (Appendix). The arrival date of Hooded Mergansers advanced by 32 days. By contrast, Greater and Lesser yellowlegs arrived 11 and 22 days later, respectively. Overall, for those species
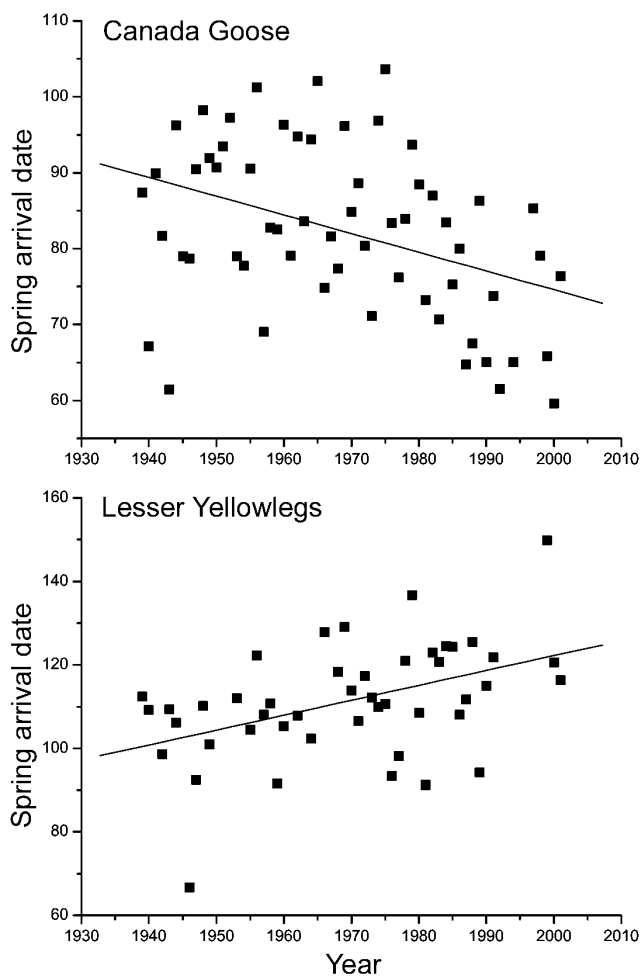

that arrived significantly earlier, dates of arrival advanced by 6 to 32 days for Anseriformes, 7 to 20 days for Charadriiformes, and 8 to 19 days for Passeriformes.

Forty-five of the 96 species analyzed typically breed at Delta Marsh (Underwood and den Haan 2000). Of those 45 species, 14 showed significantly earlier arrivals over time (Appendix). By contrast, of the 51 species of nonbreeders, 11 showed significantly earlier arrivals and 2 showed significantly later arrivals over time. For orders containing more than six species, we found only slightly higher proportions of breeders that showed significant trends over time as compared with nonbreeding Anseriformes and Passeriformes, whereas the opposite held for Charadriiformes (Table 1).

Of all species considered, 64 were shortdistance migrants, and 21 of those showed significant trends of earlier arrival over time. Of the 32 species of long-distance migrants, six showed a significant relationship between arrival date and time. Most anseriforms were
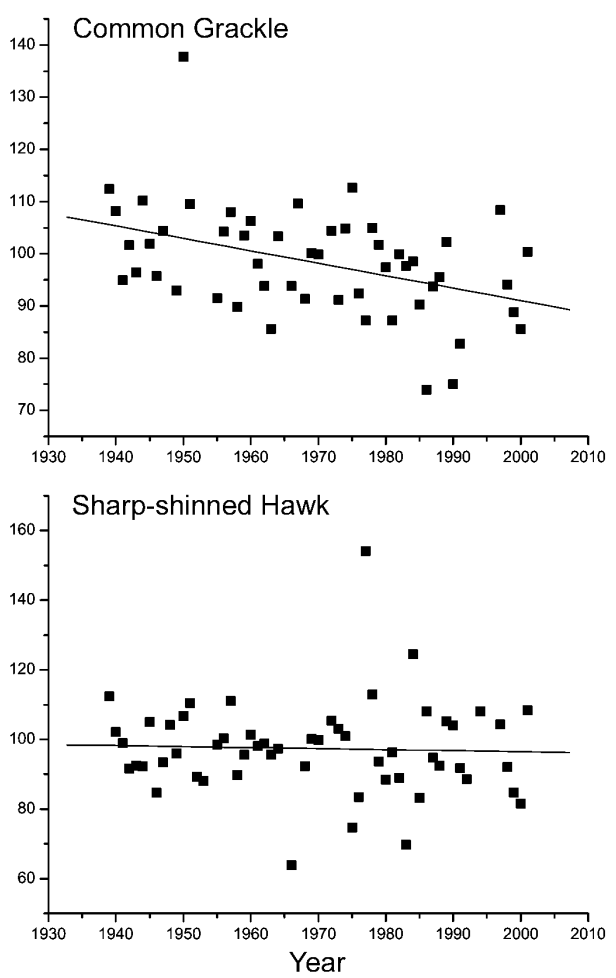

FIG. 3. Long-term trends in spring arrival dates over time (1939-2001) for four representative species at Delta Marsh, Manitoba (see Appendix for statistical values). Arrival dates (Julian) are as follows: January (1-31), February (32-59), March (60-90), April (91-120), and May (121-151). 
classified as short-distance migrants; of those, half showed significantly earlier arrival dates over the 63-year period (Table 1). Species of Charadriiformes were mainly long-distance migrants; of those, only one arrived significantly earlier. The passerines were represented by about half short-distance and half long-distance migrants (Table 1). A slightly higher proportion of short-distance migrants than long-distance migrants showed significant trends toward earlier arrival (Table 1).

\section{Influence of Temperature on Arrival Date}

The arrival dates of 44 of 96 species were significantly related to the temperature for the month of their arrival (Table 2). Forty-three of those species showed significantly negative relationships indicating that birds arrived earlier with increasing temperature (Table 2). The Marbled Godwit was the only species that showed a significantly positive trend. Overall, there were 84 negative trends and 12 positive trends, which implies that, for most species, as mean monthly temperature increases, arrival dates become earlier. All anseriforms, except for the Greater White-fronted Goose and Snow Goose, arrived significantly earlier with higher temperatures (Table 2). The Canada Goose and Mallard were among those that exhibited a strong negative relationship of arrival date with mean monthly temperature (Fig. 4). Among the Charadriiformes, only the Killdeer and Wilson's Snipe arrived significantly earlier as spring temperatures increased (Table 2). Of the passerines, the Common Grackle showed the strongest trend toward earlier arrival with warmer spring temperatures (Table 2; Fig. 4). For 41 of the species, the relationships between arrival date and year and between arrival date and temperature were both nonsignificant. Fifteen species showed significantly earlier arrival dates with both time and temperature, and 10 of those were anseriforms. Ten species arrived significantly earlier in relation to time but did not show a significant relationship with temperature. Similarly, Greater and Lesser yellowlegs arrived significantly later over time but showed no significant relationship with temperature. By contrast, 29 species exhibited a significant relationship of altered arrival date with temperature but not with time. Only one of those, the Marbled Godwit, arrived significantly later.

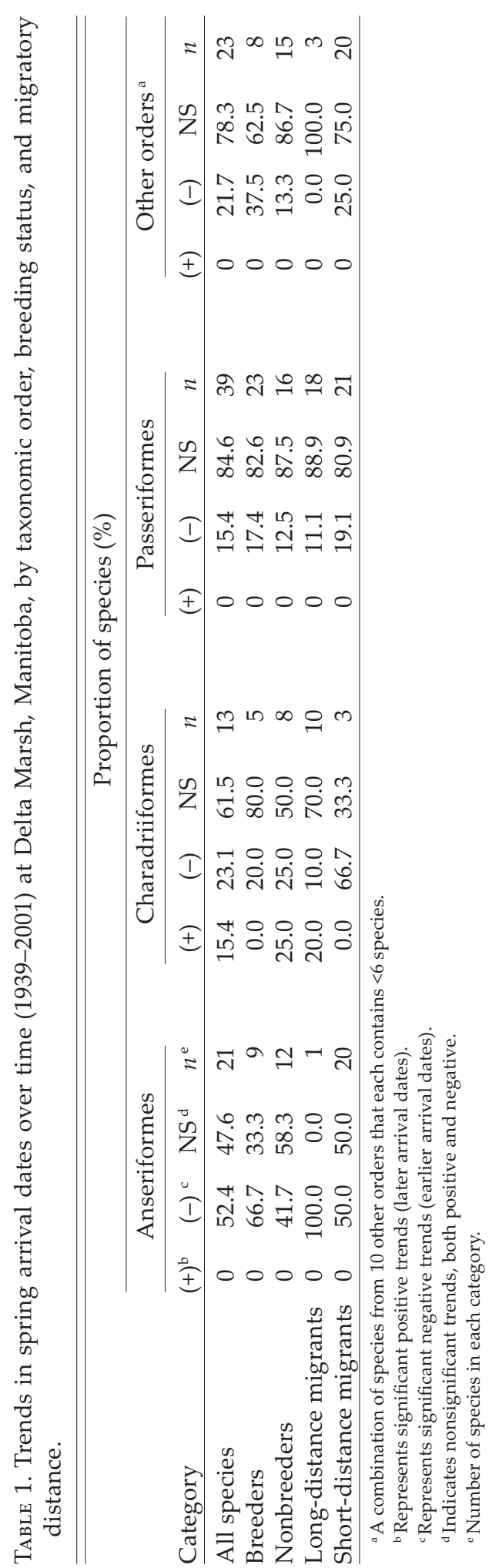


TABLE 2. Relationships between dates of spring arrival and mean temperatures in the month of arrival (1939-2001) for 96 species of birds at Delta Marsh, Manitoba.

\begin{tabular}{|c|c|c|c|c|}
\hline Order & Common name & $P$ & $r^{2}$ & $\Delta$ date/degree $\uparrow^{a}$ \\
\hline Anseriformes & $\begin{array}{l}\text { Greater White-fronted Goose } \\
\text { Snow Goose } \\
\text { Canada Goose } \\
\text { Tundra Swan } \\
\text { Gadwall } \\
\text { American Wigeon } \\
\text { Mallard } \\
\text { Blue-winged Teal } \\
\text { Northern Shoveler } \\
\text { Northern Pintail } \\
\text { Green-winged teal } \\
\text { Canvasback } \\
\text { Redhead } \\
\text { Ring-necked duck } \\
\text { Lesser Scaup } \\
\text { Bufflehead } \\
\text { Common Goldeneye } \\
\text { Hooded Merganser } \\
\text { Common Merganser } \\
\text { Red-breasted Merganser } \\
\text { Ruddy Duck }\end{array}$ & $\begin{array}{r}0.311 \\
0.328 \\
<0.001 \\
0.008 \\
0.001 \\
0.007 \\
<0.001 \\
<0.001 \\
<0.001 \\
0.005 \\
<0.001 \\
<0.001 \\
<0.001 \\
<0.001 \\
<0.001 \\
<0.001 \\
0.001 \\
0.013 \\
0.047 \\
0.005 \\
<0.001\end{array}$ & $\begin{array}{l}0.027 \\
0.020 \\
0.449 \\
0.123 \\
0.175 \\
0.130 \\
0.484 \\
0.435 \\
0.349 \\
0.128 \\
0.257 \\
0.323 \\
0.277 \\
0.287 \\
0.249 \\
0.289 \\
0.190 \\
0.152 \\
0.069 \\
0.159 \\
0.387\end{array}$ & $\begin{array}{l}-0.79 \\
-0.63 \\
-2.14 \\
-1.16 \\
-1.36 \\
-1.06 \\
-1.87 \\
-1.78 \\
-1.53 \\
-1.23 \\
-1.60 \\
-1.34 \\
-1.69 \\
-1.68 \\
-1.33 \\
-1.30 \\
-1.63 \\
-2.63 \\
-0.86 \\
-1.42 \\
-1.49\end{array}$ \\
\hline Podicipediformes & $\begin{array}{l}\text { Pied-billed Grebe } \\
\text { Horned Grebe } \\
\text { Red-necked Grebe } \\
\text { Western Grebe }\end{array}$ & $\begin{array}{l}0.008 \\
0.017 \\
0.499 \\
0.117\end{array}$ & $\begin{array}{l}0.134 \\
0.126 \\
0.010 \\
0.053\end{array}$ & $\begin{array}{r}-1.15 \\
-1.40 \\
0.51 \\
-0.89\end{array}$ \\
\hline Pelecaniformes & $\begin{array}{l}\text { American White Pelican } \\
\text { Double-crested Cormorant }\end{array}$ & $\begin{array}{l}0.651 \\
0.035\end{array}$ & $\begin{array}{l}0.004 \\
0.088\end{array}$ & $\begin{array}{l}-0.18 \\
-0.96\end{array}$ \\
\hline Ciconiiformes & $\begin{array}{l}\text { American Bittern } \\
\text { Great Blue Heron } \\
\text { Black-crowned Night-Heron }\end{array}$ & $\begin{array}{l}0.001 \\
0.129 \\
0.277\end{array}$ & $\begin{array}{l}0.190 \\
0.044 \\
0.024\end{array}$ & $\begin{array}{r}-1.32 \\
-0.71 \\
0.67\end{array}$ \\
\hline Falconiformes & $\begin{array}{l}\text { Northern Harrier } \\
\text { Sharp-shinned Hawk } \\
\text { Cooper's Hawk } \\
\text { Red-tailed Hawk } \\
\text { Rough-legged Hawk } \\
\text { American Kestrel }\end{array}$ & $\begin{array}{r}<0.001 \\
0.940 \\
0.680 \\
0.476 \\
0.668 \\
0.930\end{array}$ & $\begin{array}{l}0.323 \\
0.000 \\
0.004 \\
0.011 \\
0.004 \\
0.000\end{array}$ & $\begin{array}{r}-2.59 \\
-0.06 \\
-0.28 \\
0.48 \\
-0.24 \\
-0.05\end{array}$ \\
\hline Gruiformes & $\begin{array}{l}\text { Sora } \\
\text { American Coot } \\
\text { Sandhill Crane }\end{array}$ & $\begin{array}{l}0.154 \\
0.001 \\
0.131\end{array}$ & $\begin{array}{l}0.047 \\
0.178 \\
0.045\end{array}$ & $\begin{array}{l}-0.80 \\
-1.03 \\
-0.60\end{array}$ \\
\hline Charadriiformes & $\begin{array}{l}\text { Killdeer } \\
\text { Greater Yellowlegs } \\
\text { Lesser Yellowlegs } \\
\text { Willet } \\
\text { Spotted Sandpiper } \\
\text { Marbled Godwit } \\
\text { Wilson's Snipe } \\
\text { Wilson's Phalarope } \\
\text { Franklin's Gull } \\
\text { Ring-billed Gull }\end{array}$ & $\begin{array}{r}<0.001 \\
0.665 \\
0.345 \\
0.118 \\
0.176 \\
0.012 \\
0.005 \\
0.627 \\
0.744 \\
0.122\end{array}$ & $\begin{array}{l}0.312 \\
0.004 \\
0.020 \\
0.059 \\
0.044 \\
0.144 \\
0.150 \\
0.006 \\
0.002 \\
0.060\end{array}$ & $\begin{array}{r}-1.20 \\
0.26 \\
-0.87 \\
-0.99 \\
-0.89 \\
1.49 \\
-1.72 \\
-0.24 \\
-0.15 \\
-1.26\end{array}$ \\
\hline
\end{tabular}


TABLE 2. Continued.

\begin{tabular}{|c|c|c|c|c|}
\hline Order & Common name & $P$ & $r^{2}$ & $\Delta$ date/degree $\uparrow^{\mathrm{a}}$ \\
\hline \multirow[t]{3}{*}{ Charadriiformes } & Herring Gull & 0.278 & 0.022 & -0.54 \\
\hline & Forster's Tern & 0.152 & 0.045 & -0.83 \\
\hline & Black Tern & 0.079 & 0.065 & 0.61 \\
\hline Columbiformes & Mourning Dove & 0.143 & 0.037 & -0.78 \\
\hline Strigiformes & Short-eared Owl & 0.505 & 0.012 & -0.75 \\
\hline Caprimulgiformes & Common Nighthawk & 0.079 & 0.079 & 1.14 \\
\hline Coraciiformes & Belted Kingfisher & 0.017 & 0.103 & -0.97 \\
\hline Piciformes & Northern Flicker & 0.001 & 0.177 & -1.63 \\
\hline \multirow[t]{39}{*}{ Passeriformes } & Least Flycatcher & 0.449 & 0.013 & -0.45 \\
\hline & Eastern Phoebe & 0.189 & 0.034 & -0.68 \\
\hline & Western Kingbird & 0.523 & 0.089 & 0.27 \\
\hline & Eastern Kingbird & 0.126 & 0.048 & -0.93 \\
\hline & Horned Lark & 0.289 & 0.028 & -0.73 \\
\hline & Purple Martin & 0.109 & 0.055 & 0.82 \\
\hline & Tree Swallow & 0.107 & 0.051 & -0.52 \\
\hline & Barn Swallow & 0.813 & 0.001 & 0.12 \\
\hline & Brown Creeper & 0.642 & 0.005 & -0.36 \\
\hline & House Wren & 0.107 & 0.053 & -0.98 \\
\hline & Marsh Wren & 0.152 & 0.053 & -0.94 \\
\hline & Ruby-crowned Kinglet & 0.010 & 0.138 & -1.28 \\
\hline & Hermit Thrush & 0.038 & 0.081 & -1.12 \\
\hline & American Robin & 0.017 & 0.099 & -1.01 \\
\hline & Gray Catbird & 0.335 & 0.019 & -0.51 \\
\hline & Brown Thrasher & 0.032 & 0.097 & -1.37 \\
\hline & Yellow Warbler & 0.177 & 0.035 & -0.38 \\
\hline & Yellow-rumped Warbler & 0.858 & 0.001 & -0.08 \\
\hline & Palm Warbler & 0.362 & 0.018 & -0.39 \\
\hline & American Redstart & 0.026 & 0.110 & -0.67 \\
\hline & Common Yellowthroat & 0.088 & 0.073 & -0.64 \\
\hline & Wilson's Warbler & 0.013 & 0.151 & -0.90 \\
\hline & American Tree Sparrow & 0.001 & 0.191 & -1.46 \\
\hline & Clay-colored Sparrow & 0.470 & 0.013 & 0.42 \\
\hline & Vesper Sparrow & 0.363 & 0.021 & -0.69 \\
\hline & Fox Sparrow & 0.012 & 0.118 & -1.24 \\
\hline & Song Sparrow & 0.327 & 0.018 & -0.70 \\
\hline & White-throated Sparrow & 0.130 & 0.042 & -0.90 \\
\hline & Harris's Sparrow & 0.405 & 0.015 & -0.31 \\
\hline & White-crowned Sparrow & 0.407 & 0.016 & -0.53 \\
\hline & Dark-eyed Junco & $<0.001$ & 0.391 & -1.55 \\
\hline & Bobolink & 0.858 & 0.001 & -0.16 \\
\hline & Red-winged Blackbird & 0.001 & 0.195 & -1.29 \\
\hline & Western Meadowlark & 0.031 & 0.079 & -0.90 \\
\hline & Yellow-headed Blackbird & 0.641 & 0.004 & 0.20 \\
\hline & Common Grackle & $<0.001$ & 0.253 & -2.10 \\
\hline & Brown-headed Cowbird & 0.852 & 0.001 & -0.15 \\
\hline & Baltimore Oriole & 0.009 & 0.161 & -1.13 \\
\hline & Purple Finch & 0.009 & 0.136 & -2.21 \\
\hline
\end{tabular}

\footnotetext{
${ }^{a}$ Represents the change in arrival date for every $1^{\circ} \mathrm{C}$ change in temperature.
} 

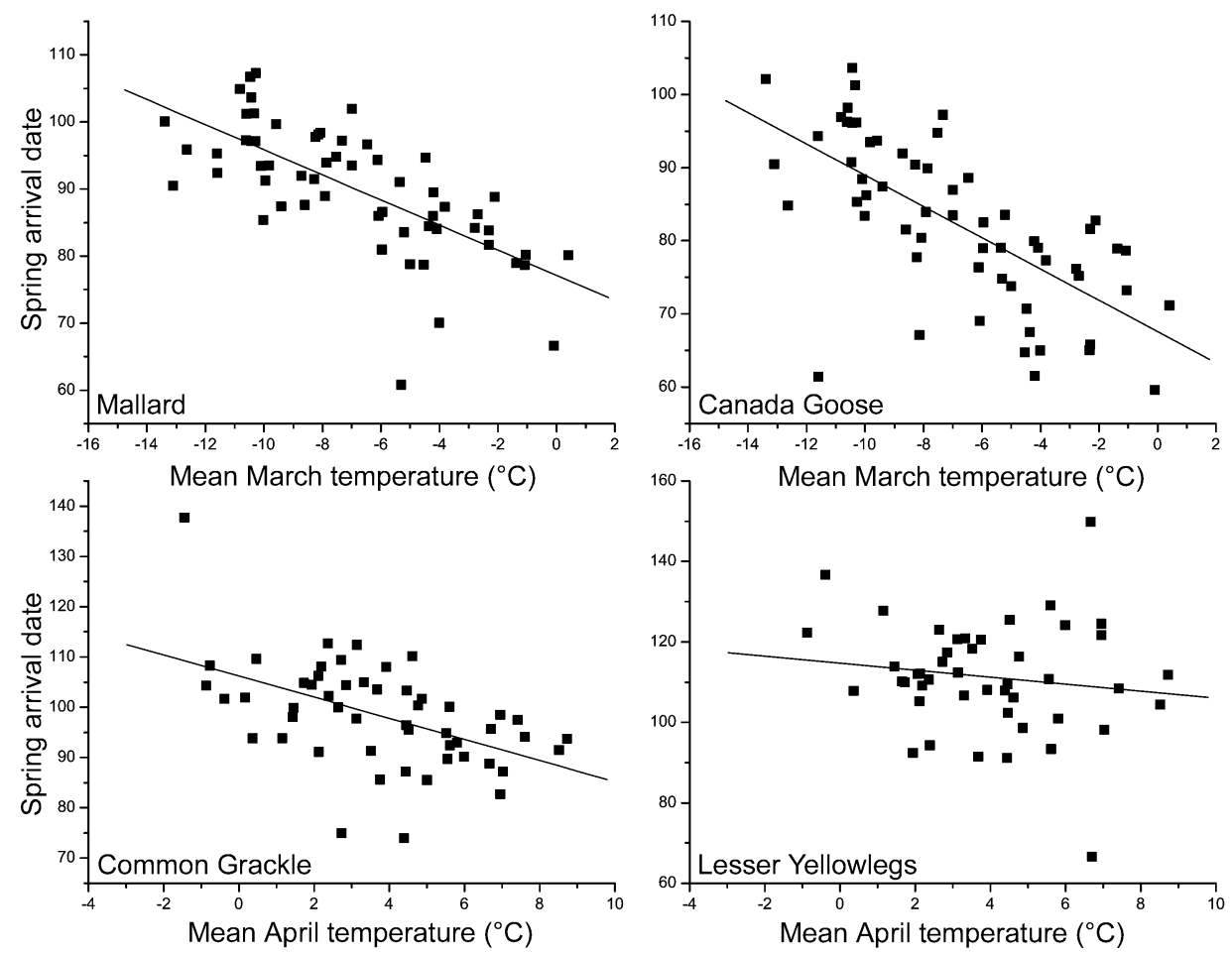

FIG. 4. Relationships between spring arrival date and mean monthly temperature (1939-2001) for four representative species at Delta Marsh, Manitoba (see Table 2 for statistical values). Arrival dates (Julian) are as follows: January (1-31), February (32-59), March (60-90), April (91-120), and May (121-151).

Using regression equations from the temperature-related analyses (Table 2), we estimated the change in arrival date with an increase of $1^{\circ} \mathrm{C}$ for each species. Anseriforms arrived from 0.6 to 2.6 days earlier, with the Hooded Merganser being the most affected of all species (Table 2). For Charadriiformes, arrivals were from 1.7 days earlier to 1.5 days later, whereas passerines arrived 2.2 days earlier to 0.8 days later with a $1^{\circ} \mathrm{C}$ increase in temperature.

\section{Discussion}

Species that arrived earlier at Delta Marsh had more variable arrival dates as represented by their standard deviations. Similarly, spring migrants arriving earlier in Europe were more variable in their arrival dates (Mason 1995, Tryjanowski et al. 2002), and species arriving earlier in the season at two other sites in North America had greater ranges in arrival dates compared with those arriving later (Weydemeyer
1973, Hagan et al. 1991). The larger variability in early arrivals may result from adverse weather conditions that are more likely to occur earlier in the season and delay this group of migrants (Elkins 1983). Alternatively, later migrants are more likely to be long-distance migrants whose timing of migration may not be as strongly influenced by external stimuli (Hagan et al. 1991).

Mean monthly temperatures from the Winnipeg International Airport revealed consistent trends of increasing temperatures during the months of the study, though trends for February and March were stronger than those for April and May. The actual change in temperature ranged from $0.6^{\circ} \mathrm{C}$ in April to $3.8^{\circ} \mathrm{C}$ in February. We believe that these temperature increases over the long term are significant biologically, because temperature increases of $<1^{\circ} \mathrm{C}$ have been interpreted as climate warming (Houghton et al. 1996, International Institute for Sustainable Development and Manitoba Clean Environment Commission 2001). The lack of 
significant trends in temperatures over time is likely related to the large fluctuations in temperatures from year to year (Fig. 2). However, the general trend was clearly for increasing temperatures for all four months, which provided evidence for climate warming.

About one-third of the species we considered showed significant trends in arrival date over the 63 -year study period. All but two of those species arrived significantly earlier. Greater and Lesser yellowlegs were the only species that arrived significantly later. Arrival dates advanced substantially for some species (e.g. Hooded Mergansers arrived 32 days earlier by the end of the study period). Thus, several species have advanced their migration arrival date at Delta Marsh over time as temperatures have increased.

A study from Aweme, Manitoba, $115 \mathrm{~km}$ southwest of Delta Marsh, provides some additional comparative evidence for advanced migration arrival dates during the earlier part of the 20th century. Criddle (1922) summarized dates of first spring sightings of birds from 1895 to 1920. Similar to our findings, Horned Larks were, on average, the first spring migrants to arrive, and Common Nighthawks among the last. As an example, the mean arrival dates for the Canada Goose, Mallard, and Killdeer at Delta Marsh (1939-2001) have each advanced three days compared with the mean arrival dates for those species between 1895 and 1920 at Aweme. However, not all species have advanced between these two periods, and these comparisons should be interpreted cautiously, because the habitats and observational effort at the two sites differed substantially.

In comparison with studies on long-term trends in spring arrivals in Europe, our study showed a lower proportion of species with significant trends in arrival dates. In Poland, Tryjanowski et al. (2002) revealed significant trends toward earlier spring arrival in $69 \%$ of 13 species. In Britain, Mason (1995) documented significant trends in arrival dates for $39 \%$ of spring migrants, but only half those species were arriving earlier. Our results, based on a larger number of species, were more similar to those of another study in North America. Butler (2003) found that in the second half of the 20th century, $27 \%$ of 103 species examined showed significant trends toward earlier spring arrival, whereas $26 \%$ of the 96 species we examined arrived significantly earlier.
For many species, spring arrival dates were significantly related to mean monthly temperatures, which suggests that climate warming is responsible in part for advancing arrival dates. For example, the Canada Goose arrived significantly earlier over time and showed a strong relationship between arrival date and spring temperatures (Figs. 3 and 4). However, other species, such as the Snow Goose, arrived earlier over time, but there was no significant relationship between arrival date and temperature. Arrival dates of this and other species with conflicting trends were likely influenced by factors other than temperature. In particular, Greater and Lesser yellowlegs were the only species to arrive significantly later, but their arrival dates were not significantly related to temperature (Figs. 3 and 4). The later arrivals of these species may be related to other potential factors, such as population changes, habitat alteration in the area, or environmental conditions other than temperature. Many environmental factors affect migration; for example, Snow Geese migrating through Manitoba responded not to a single aspect of their environment alone but rather to a complex of favorable wind conditions, temperature, and humidity (Blokpoel and Richardson 1978). Unfortunately, we do not have further data to address these perplexing later arrivals.

In general, many of the species that arrived earlier with time and showed a significant relationship between arrival date and temperature were those that arrived earlier in the season. For example, waterfowl as a group had the highest proportion of earlier arrivals and many significant relationships between arrival date and temperature. These species tended to arrive earlier in the season where temperature change in the area was more pronounced. The Hooded Merganser was one species of particular interest, because over the 63-year period, its arrival date advanced by 32 days and showed a strongly positive relationship with temperature; it arrived an estimated 2.6 days earlier for every $1^{\circ} \mathrm{C}$ increase. Clearly, the mean temperatures for April did not increase sufficiently to account for this large increment over time. However, other potential factors in addition to temperature, such as population size (e.g. Tryjanowski and Sparks 2001), may have influenced arrival dates in this species. Indeed, an increase in Hooded Merganser populations has been reported over many parts of its range in recent decades (Dugger et al. 1994). 
The American Robin is one of a few species whose spring arrival dates have been examined at different locations in North America. Inouye et al. (2000) determined that, from 1974 to 1994, American Robins arrived 5.4 days earlier at their high-altitude breeding grounds in Colorado and 7.0 days earlier in Michigan. However, those trends were not statistically significant. During the same period at Delta Marsh, American Robins arrived 15.9 days earlier, a much more pronounced and statistically significant change $\left(r^{2}=0.450, P=0.001\right)$. Though American Robins showed a trend toward earlier arrival at higher altitude, vegetation phenology did not advance concurrently in those breeding areas, which may lead to a mismatch between arrival and optimal food supply (Inouye et al. 2000).

Several authors have discussed potentially negative implications of a mismatch between arrival dates of migrants and optimal conditions at breeding sites (Lack 1960, Sparks 1999, Inouye et al. 2000, Both and Visser 2001). For example, a longer growing season may increase juvenile survivorship; however, arrival dates may not be synchronous with optimal food supply for adult birds (Crick et al. 1997). Our findings indicate that several migrants showing a significant trend of earlier arrival dates over time also demonstrate a negative relationship of arrival date with temperature (Table 2). The observed earlier arrival dates may be adaptive responses to increasing temperatures. Migrants that arrive earlier may be selected for because they have more and better opportunities to obtain territories on their breeding areas (Mason 1995). Indeed, Lack (1960) predicted that birds should arrive on their breeding grounds as early as survival under existing conditions is possible. However, we do not know whether the phenology of food sources or nesting habitat have also advanced at Delta Marsh to match the earlier arrivals of some migrants.

Some birds respond to rising spring air temperatures and initiate migration on approximately the second day following the largest temperature increase in the spring (Žalakevičius 1990), which serves to optimize flight conditions (Žalakevičius 1993). In fact, Richardson (1990) reviewed the relationship between daily weather phenomena and migration intensity and confirmed that the best conditions for migration appeared to be calm winds or tail winds in the direction of the migration pathways, low baro- metric pressure, lack of precipitation, and warm temperatures. In addition, there appears to be a reduced connection between weather and migration for long-distance migrants observed far from their take-off location. Koike and Higuchi (2002) found that despite annual temperatures showing no significant increase in the breeding area where advanced laying dates were observed, they increased throughout migration and overwintering areas. However, we believe that the ultimate arrival dates are not only affected by temperatures at overwintering areas and along the migration path, but also at the final destination. This is because, over time, individuals that arrive too late to exploit the advancing phenologies would be selected against. Ultimately, weather at the take-off point, en route, and at the final destination is expected to influence timing of bird migration (Richardson 1978). Birds whose spring migration dates were affected by temperature returned up to 2.6 days earlier at Delta Marsh, with a $1^{\circ} \mathrm{C}$ increase in temperature. Similarly, Sparks (1999) found that Common Cuckoos (Cuculus canorus) were arriving 1.8 days earlier in Britain for every $1^{\circ} \mathrm{C}$ increase in temperature.

If Delta Marsh migrants do not respond to increases in spring temperatures by advancing their migration dates, they may alter other aspects of their life histories, as noted previously when clutch initiation dates were examined. For example, although Yellow Warblers did not return significantly earlier over time, Goossen and Sealy (1982) found that clutches were initiated significantly earlier during warmer springs at Delta Marsh. Further work is needed to confirm those trends over long periods.

About $40 \%$ of waterbirds in our study demonstrated significant trends in spring arrival dates over time, as did $\sim 20 \%$ of landbirds. Most of those were passerines. Waterfowl may be arriving earlier as a result of open water appearing earlier along the migration route, as they depend on those sites as stopover areas. Because the presence of open water plays a primary role in the migration of waterfowl, dates of ice break-up would likely be a better predictor of their arrival dates. However, those data were not available for the Delta Marsh area.

Other than an association with water, there were no clear characteristics identifying species with significant changes in arrival dates over time. There were comparable numbers of species 
that breed at Delta Marsh showing significant trends over time as there were for species that use the area only as a stopover site. Anseriforms that breed at Delta Marsh showed a somewhat higher proportion of negative trends than the nonbreeders (Table 1); but overall, breeding status did not appear to influence which species were migrating earlier. It is possible, however, that birds are breeding earlier in these locations, and it remains to be determined whether arrival date is related to clutch initiation date.

Similarly, there was little difference between short-distance and long-distance migrants showing significant trends within the Passeriformes and other orders with less than six species (Table 1). Most anseriforms were classified as short-distance migrants, whereas most charadriiforms were identified as longdistance migrants, including the Greater and Lesser yellowlegs, the only species that demonstrated significant trends toward later arrival. Species that migrate from tropical climates tend to arrive on the breeding grounds later than those that arrive from temperate areas (Hagan et al. 1991). The effect of global climate warming is felt more strongly at higher latitudes (Dunn and Winkler 1999, Pounds et al. 1999); therefore, migrants from temperate areas may experience warming cues earlier than tropical migrants and initiate their spring migration earlier. That may partially explain why we observed more negative trends in arrival of anseriforms, which are short-distance migrants, than of the longdistance-migrant charadriiforms, which exhibited more positive relationships between arrival date and year. Tryjanowski et al. (2002) also found that short-distance migrants from Europe showed a more pronounced trend toward earlier spring arrival than long-distance migrants from Africa. Likewise, Butler (2003) found that short-distance migrants taking off from the southern United States, as compared with those that winter south of the United States, arrived disproportionately earlier. Butler (2003) suggested that this is attributable to the direct effect of cold fronts during spring for shortdistance migrants, whereas long-distance migrants would rely more on photoperiod.

In summary, several species have advanced their spring arrival date over 63 years at Delta Marsh, and for many species, those advances were linked to concurrent warming trends in the area. Only two species arrived significantly later over time, but the arrival dates of those species were not related to temperature. There were no characteristics that clearly identified a group of birds that arrived earlier. However, there were slight trends for waterbirds, birds that breed at Delta Marsh, and short-distance migrants to arrive earlier over time. Waterfowl appeared to be more sensitive to the effects of warming trends, possibly because they overwinter in more temperate areas, where climate warming is more pronounced. In general, climate warming appears to be influencing spring arrival dates of some migratory birds in Manitoba. The next steps will be to consider the effects of climate warming on other life-history parameters and to determine whether earlier spring migration is a reason for conservation concern.

\section{Acknowledgments}

We thank S. LaRivière and the Delta Waterfowl and Wetlands Research Station for granting permission to use these migration data and W. Gorsuch for assistance in accessing them. This study would not have been possible without the work of many researchers, staff, and students at the research station over the past 63 years. We also thank J. Hare and K. Beal for statistical advice and M. J. Uddin for assistance with weather data. Comments from G. Davoren, D. Hussell, and D. Inouye helped to improve our manuscript. This research was funded in part by a Natural Sciences and Engineering Research Council of Canada discovery grant to S. G. Sealy.

\section{Literature Cited}

American Ornithologists' Union. 1998. Checklist of North American Birds, 7th ed. American Ornithologists' Union, Washington, D.C.

Barrett, R. T. 2002. The phenology of spring bird migration to north Norway. Bird Study 49:270-277.

Blokpoel, H., and W. J. Richardson. 1978. Weather and spring migration of Snow Geese across southern Manitoba. Oikos 30:350-363.

Both, C., AND M. E. Visser. 2001. Adjustment to climate change is constrained by arrival date in a long-distance migrant bird. Nature 411: 296-298.

Bradley, N. L., A. C. Leopold, J. Ross, and W. HufFAKer. 1999. Phenological changes reflect 
climate change in Wisconsin. Proceedings of the National Academy of Sciences USA 96: 9701-9704.

Brown, J. L., S.-H. Li, and N. Bhagabati. 1999. Long-term trend toward earlier breeding in an American bird: A response to global warming? Proceedings of the National Academy of Sciences USA 96:5565-5569.

Butler, C. J. 2003. The disproportionate effect of global warming on the arrival dates of shortdistance migratory birds in North America. Ibis 145:484-495.

Crick, H. Q. P., C. Dudley, D. E. Glue, and D. L. Thomson. 1997. UK birds are laying eggs earlier. Nature 388:526.

CRIDDle, N. 1922. A calendar of bird migration. Auk 39:41-49.

DEN HAAN, H. 1997. Delta Marsh Bird Observatory interim report: 1997. University of Manitoba Field Station (Delta Marsh) Annual Report 32:23-26.

Dugger, B. D., K. M. Dugger, and L. H. Fredrickson. 1994. Hooded Merganser (Lophodytes cucullatus). In The Birds of North America, no. 98 (A. Poole and F. Gill, Eds.). Academy of Natural Sciences, Philadelphia, and American Ornithologists' Union, Washington, D.C.

Dunn, P. O., And D. W. Winkler. 1999. Climate change has affected the breeding date of Tree Swallows throughout North America. Proceedings of the Royal Society of London, Series B 266:2487-2490.

Elkins, N. 1983. Weather and Bird Behaviour. T. and A. D. Poyser, Calton, United Kingdom.

Forchнаmmer, M. C., E. Post, and N. C. Stenseth. 1998. Breeding phenology and climate... Nature 391:29-30.

Goossen, J. P., and S. G. Sealy. 1982. Production of young in a dense nesting population of Yellow Warblers, Dendroica petechia, in Manitoba. Canadian Field-Naturalist 96:189-199.

Hagan, J. M., T. L. Lloyd-Evans, and J. L. Aтwood. 1991. The relationship between latitude and the timing of spring migration of North American landbirds. Ornis Scandinavica 22:129-136.

Hobson, K. A., S. G. Sealy, and H. den Haan. 1993. Patterns of migration of warblers through the dune-ridge forest, Delta Marsh, 1982 to 1984: The need for a second look. Page 322 in Proceedings of the Third Prairie Conservation and Endangered Species
Workshop (G. L. Holroyd, H. L. Dickson, M. Regnier, and H. C. Smith, Eds.). Provincial Museum of Alberta Natural History Occasional Paper no. 19, Edmonton, Alberta.

Houghton, J. T., L. G. Meira Filho, B. A. Callander, N. Harris, A. Kattenberg, and K. Maskell, Eds. 1996. Climate Change 1995: The Science of Climate Change. Cambridge University Press, Cambridge, United Kingdom.

Hussell, D. J. T. 2003. Climate change, spring temperatures, and timing of breeding of Tree Swallows (Tachycineta bicolor) in southern Ontario. Auk 120:607-618.

Inouye, D. W., B. Barr, K. B. Armitage, AND B. D. Inoure. 2000. Climate change is affecting altitudinal migrants and hibernating species. Proceedings of the National Academy of Sciences USA 97:1630-1633.

International Institute fOR Sustainable Development and Manitoba Clean Environment Commission. 2001. Manitoba and climate change: A primer. International Institute for Sustainable Development, Winnipeg, Manitoba.

Jenkins, D., And A. Watson. 2000. Dates of first arrival and song of birds during 1974-99 in mid-Deeside, Scotland. Bird Study 47: 249-251.

Koike, S., And H. Higuchi. 2002. Long-term trends in the egg-laying date and clutch size of Red-cheeked Starlings Sturnia philippensis. Ibis 144:150-152.

LACK, D. 1960. The influence of weather on passerine migration. A review. Auk 77:171-209.

Lane, R. K., and M. Pearman. 2003. Comparison of spring return dates of Mountain Bluebirds, Sialia currucoides, and Tree Swallows, Tachycineta bicolor with monthly air temperatures. Canadian Field-Naturalist 117:110-112.

MacKenzie, D. I. 1982. The dune-ridge forest, Delta Marsh, Manitoba: Overstory vegetation and soil patterns. Canadian FieldNaturalist 96:61-68.

MacKenzie, D. I., S. G. Sealy, and G. D. Sutherland. 1982. Nest-site characteristics of the avian community in the dune-ridge forest, Delta Marsh, Manitoba: A multivariate analysis. Canadian Journal of Zoology 60:2212-2223.

Mason, C. F. 1995. Long-term trends in the arrival dates of spring migrants. Bird Study 42:182-189. 
McCleery, R. H., and C. M. Perrins. 1998. ...temperature and egg-laying trends. Nature 391:30-31.

Moss, S. 1998. Predictions of the effects of global climate change on Britain's birds. British Birds 91:307-325.

Parmesan, C., And G. Yohe. 2003. A globally coherent fingerprint of climate change impacts across natural systems. Nature 421: $37-42$.

Poole, A., AND F. Gill, Eds. 1992-2002. The Birds of North America. Birds of North America, Philadelphia.

Pounds, J. A., M. P. L. Fogden, And J. H. CAMpbell. 1999. Biological response to climate change on a tropical mountain. Nature 398:611-614.

Przybylo, R., B. C. Sheldon, and J. Merilä. 2000. Climatic effects on breeding and morphology: Evidence for phenotypic plasticity. Journal of Animal Ecology 69:395-403.

Richardson, W. J. 1978. Timing and amount of bird migration in relation to weather: A review. Oikos 30:224-272.

Richardson, W. J. 1990. Timing of migration in relation to weather: Updated review. Pages 78-101 in Bird Migration: Physiology and Ecophysiology (E. Gwinner, Ed.). SpringerVerlag, Berlin.

Robbins, C. S., D. Bystrak, and P. H. Geissler. 1986. The Breeding Bird Survey: Its first fifteen years, 1965-1979. U.S. Department of the Interior, Fish and Wildlife Service, Resource Publication, no. 157.

SAgARIN, R. 2001. False estimates of the advance of spring. Nature 414:600.

SeALY, S. G. 1980. Breeding biology of Orchard Orioles in a new population in Manitoba. Canadian Field-Naturalist 94:154-158.

SHAY, J. M. 1999. Annotated vascular plant species list for the Delta Marsh, Manitoba and surrounding area. University of Manitoba Field Station (Delta Marsh) Occasional Publication no. 2, Winnipeg, Manitoba.

Sparks, T. H. 1999. Phenology and the changing pattern of bird migration in Britain. International Journal of Biometeorology 42: 134-138.

Tryjanowski, P., and T. H. Sparks. 2001. Is the detection of the first arrival date of migrating birds influenced by population size? A case study of the Red-backed Shrike Lanius collurio. International Journal of Biometeorology 45:217-219.

Tryjanowski, P., S. Kuźniak, and T. Sparks. 2002. Earlier arrival of some farmland migrants in western Poland. Ibis 144:62-68.

Underwood, T. J., AND H. E. DEN HaAn. 2000. Checklist of the Birds of Delta Marsh, 3rd ed. Delta Marsh Bird Observatory, Portage la Prairie, Manitoba.

Visser, M. E., A. J. van NoordwiJk, J. M. Tinbergen, AND C. M. Lessells. 1998. Warmer springs lead to mistimed reproduction in Great Tits (Parus major). Proceedings of the Royal Society of London, Series B 265: 1867-1870.

Weydemeyer, W. 1973. The spring migration pattern at Fortine, Montana. Condor 75: 400-413.

Wilson, W. H., Jr., D. Kipervaser, and S. A. Lilley. 2000. Spring arrival dates of Maine migratory breeding birds: 1994-1997 vs. 1899-1911. Northeastern Naturalist 7:1-6.

Winkler, D. W., P. O. DunN, AND C. E. McCulloch. 2002. Predicting the effects of climate change on avian life-history traits. Proceedings of the National Academy of Sciences USA 99:13595-13599.

ŽAlakevičIUS, M. 1990. The study of mechanisms controlling migratory take-off in spring and autumn. Acta Ornithologica Lituanica 3: 3-52.

ŽAlakevičıus, M. 1993. A study of mechanisms controlling migratory take-off of geese, thrushes and Wood Pigeon in spring and autumn: A radar study. Acta Ornithologica Lituanica 7-8:16-26.

ŽAlakevičıus, M. 1999. Global climate change impact on bird numbers, population state and distribution areas. Acta Zoologica Lituanica 9:78-89.

ZAR, J. H. 1999. Biostatistical Analysis, 4th ed. Prentice Hall, Upper Saddle River, New Jersey.

Zhang, X., L. A. Vincent, W. D. Hogg, and A. Nirsoo. 2000. Temperature and precipitation trends in Canada during the 20th century. Atmosphere-Ocean 38:395-429.

Associate Editor: R. L. Holberton 


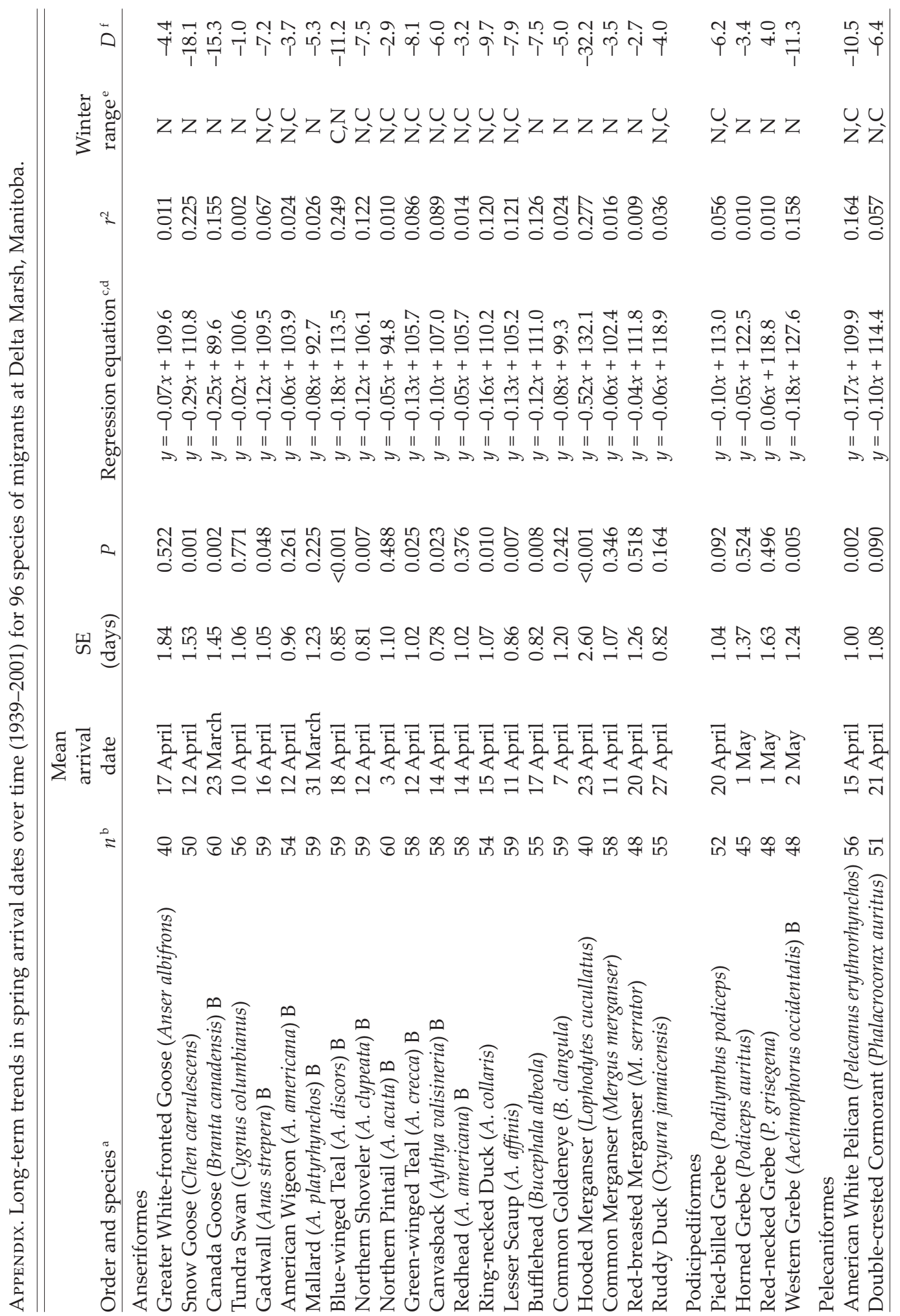




\begin{tabular}{|c|c|c|c|c|}
\hline$\vec{a}$ & הิ & 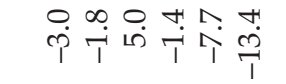 & 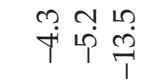 & 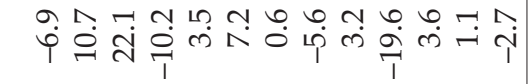 \\
\hline 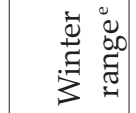 & 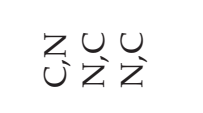 & 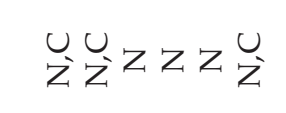 & 允允Z & 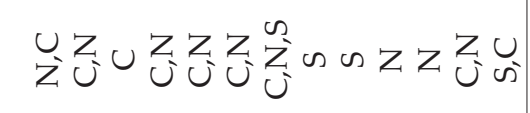 \\
\hline $\mathcal{Z}$ & 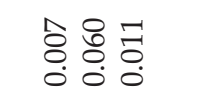 & 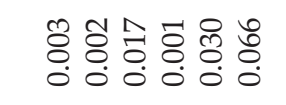 & 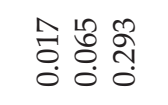 & 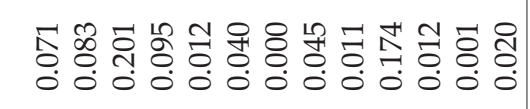 \\
\hline 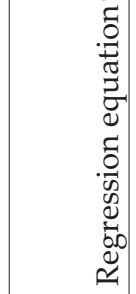 & 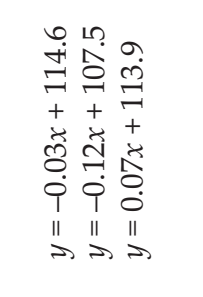 & 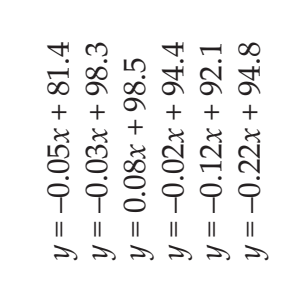 & 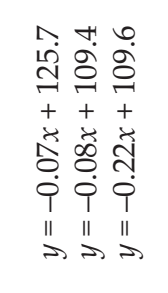 & 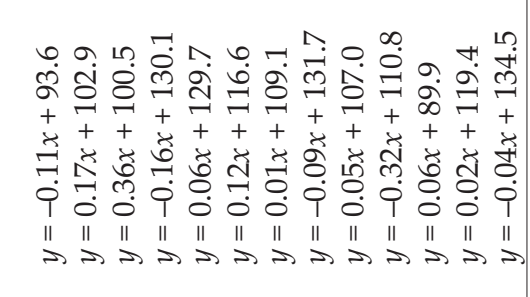 \\
\hline$a$ & 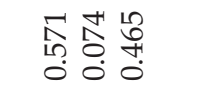 & 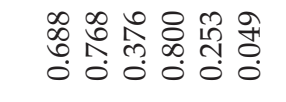 & 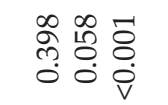 & 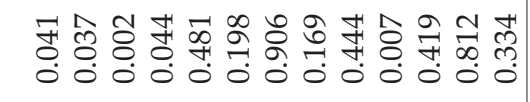 \\
\hline 떵 & 号 & 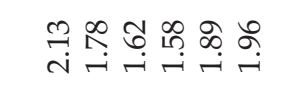 & 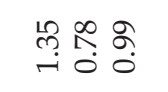 & 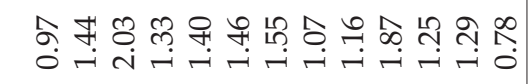 \\
\hline 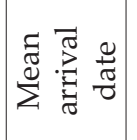 & 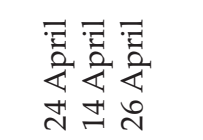 & 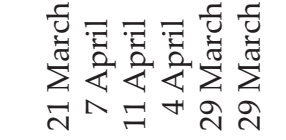 & 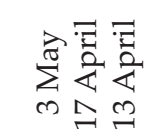 & 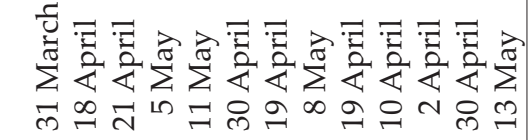 \\
\hline$=$ & 的茄 的 & 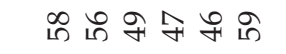 & 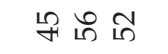 & 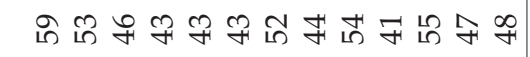 \\
\hline 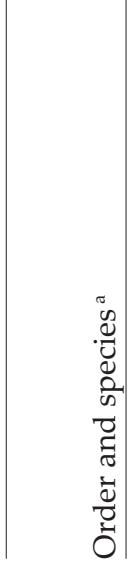 & 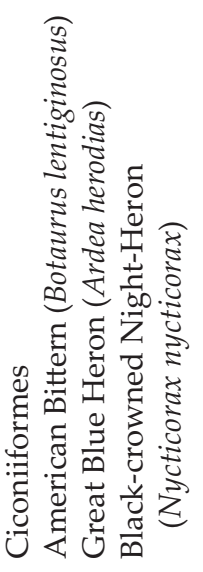 & 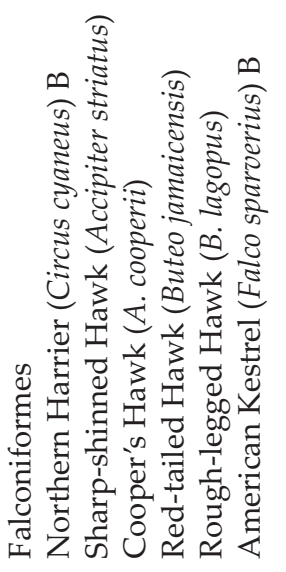 & 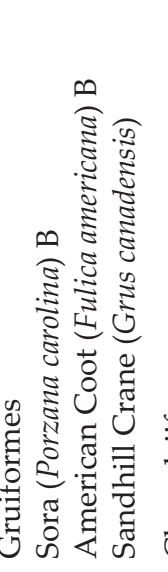 & 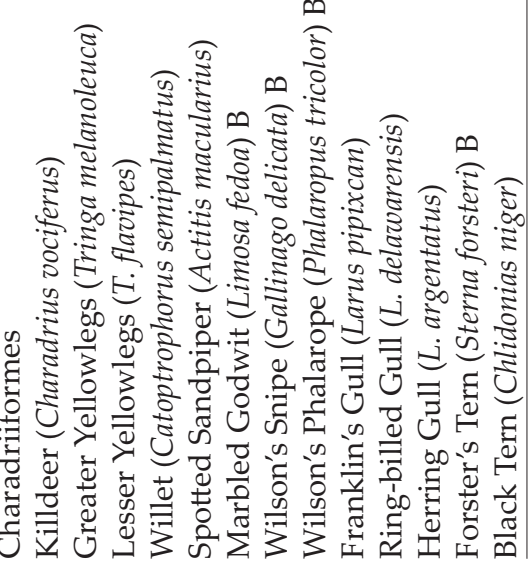 \\
\hline
\end{tabular}




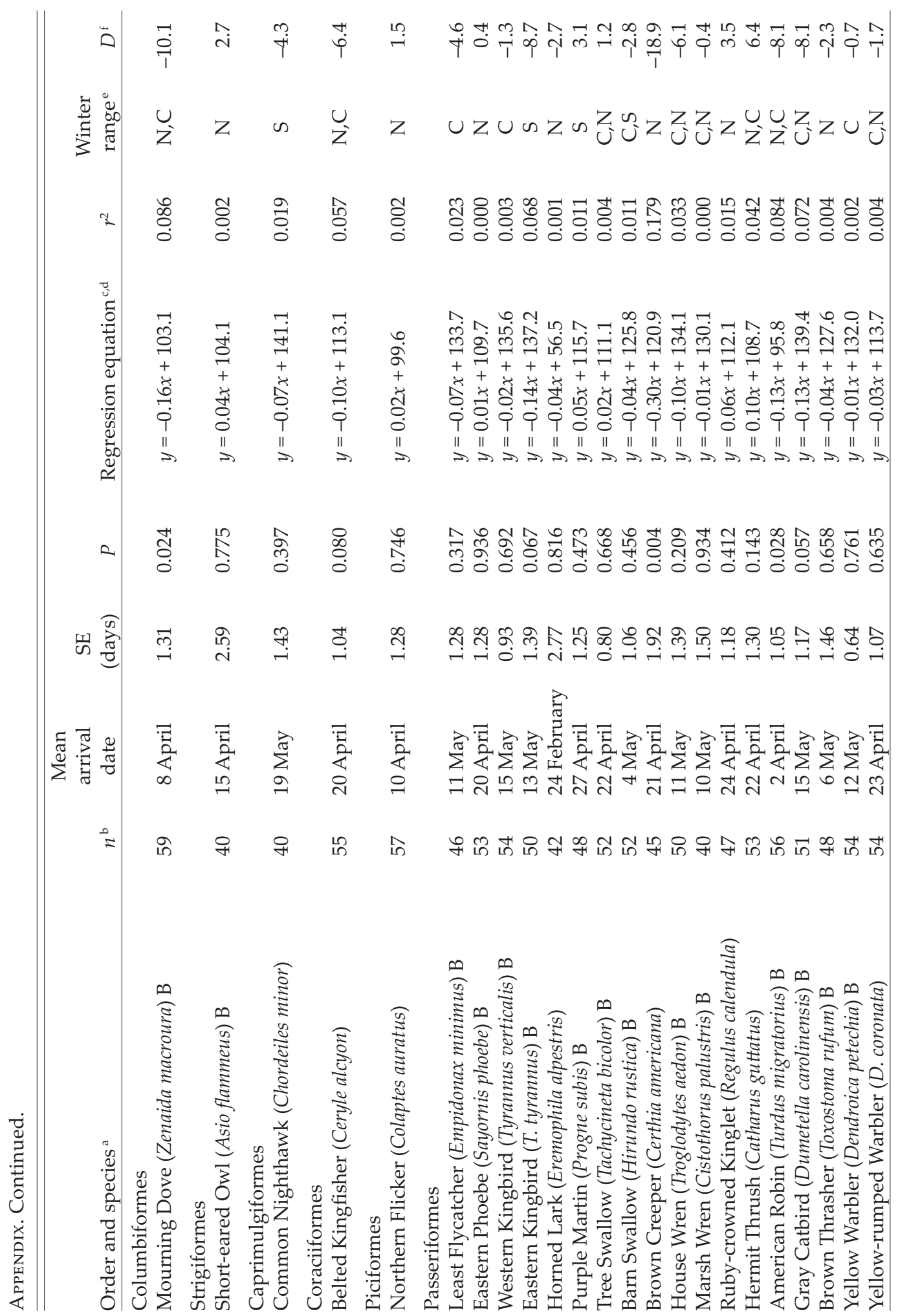




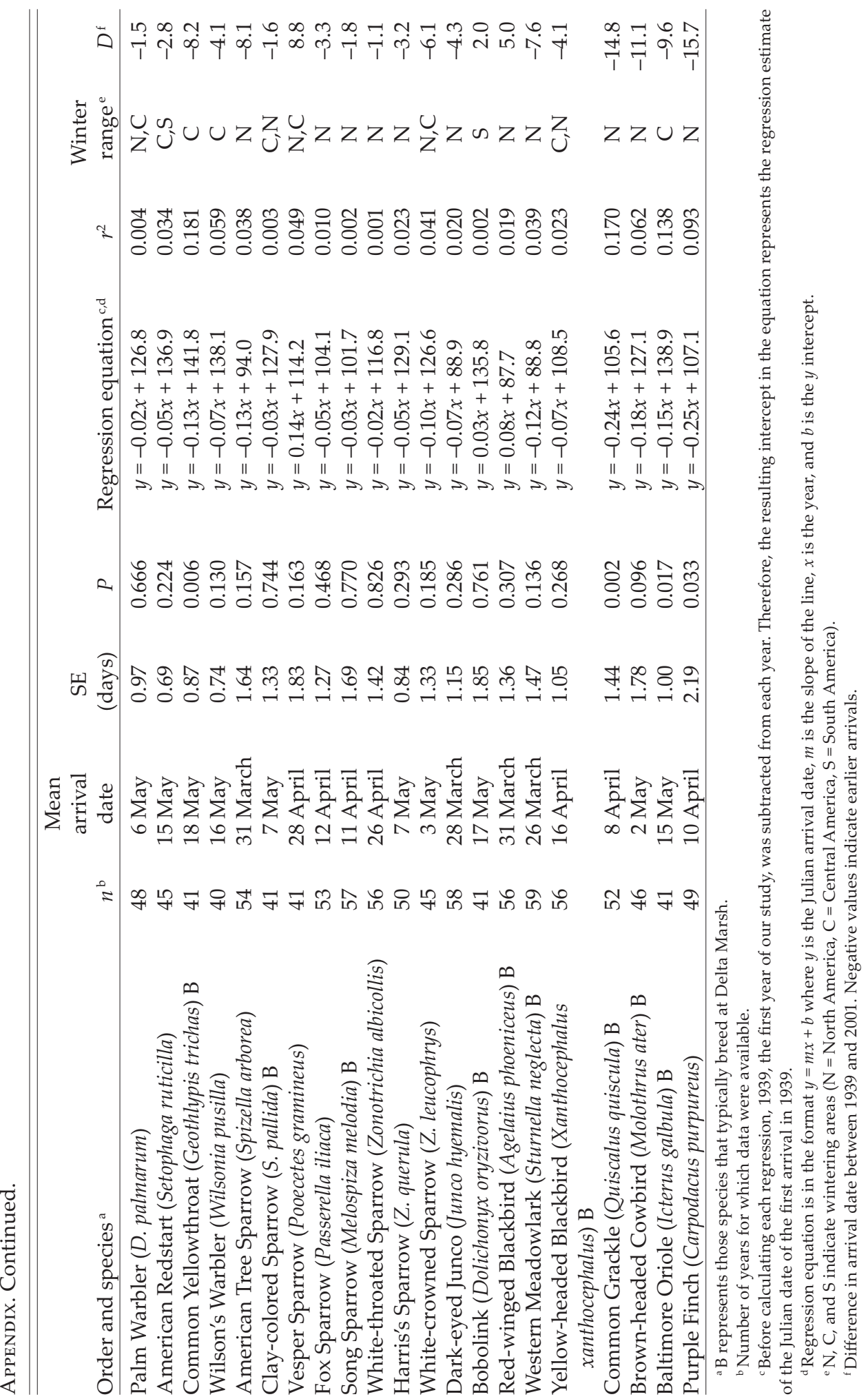

